in the matter of edication. But Government is slow to move, and is quite sure not to please everybody when it does. In the meantime let scientific societies, each anxious for the spread of knowledge on its own subject, take example by the Royal Geographical Society. Let prizes and honourable mentions be offerecl, let them be somewhat difficult of attainment, and let the distinction be matter of public award; and it will scon be seen that the scientific education of the country will have received a healthy and vigorous impulse, which will do much to spread the desired instruction through all classes of the nation.

J. A. Chessar

\section{ON THE PROGRESS OF BOTANY IN 1869} It.

WITII regard to the succession of races which have undergone a complete specific change through successive geological periods, ve have not in plants, in as far as I am aware, any such cases of " true linear types or forms which are intermediate between others because they stand in a direct genetic relation to them," as Professor Huxley appears to have made out in favour of the nedigree of the horse in his last anniversary address to the Geological Society. And I may, in regard to plants, repeat with still greater emphasis his dictum, that "it is no easy matter to find clear and unmistakable evidence of filiation among fossil animals ; for in order that such evidence should be quite satisfactory, it is necessary that we should be acquainted with all the most important features of the organisation of the animals which are supposed to be thus related, and not merely with the fragments upon which the genera and species of the palæontologist are so often based." The difficulty is much greater in the case of fossil plants ; for instead of bones, teeth, or shells, portions of internal or external skeletons, the parts preserved to us from the Tertiary period are generally those least indicative of structural organisation. Mr. Carruthers has recently (Geological Magazine, April and July 1869, and Fournal of the Geological Society, August I869) adduced satisfactory evidence of the close affinity of Sigillaria and the allied genera of the coal-period with the living Lycopodiacer, formerly suggested by Dr. Hooker, but, as he informs me, no connecting links, no specimens indeed of the whole order, have as yet been found in any of the intermediate Cretaceous or Tertiary deposits. Among the latter the presence of numerous types, to which we may plausibly refer as to the ancestors of living races, is established upon unimpeachable data ; but I have been unable to find that a single case of authentic pedigree, as successively altered from the Cretaceous through the abundant deposits of the Eocene and Miocene period to the living races, has been as yet as satisfactorily made out as that of the absolute identity of Taxodium and others above mentioned, although I feel very little doubt that such a one will yet be traced when our palæontologists will have ceased to confound and reason alike upon the best proved facts and the wildest guesses. Our late distinguished foreign member, Professor Unger, whose loss we have had so recently to deplore, had indeed, shortly before his death, putlished, under the name of "Geologie der Europäischen Waldbäume, part $x$. Laubhölzer," no less than twelve tabular pedigrees of European forest races ; but it seems to me that in this, as in another of the same eminent palrontologist's papers to which I shall presently have to refer, his speculations have been deduced more freely from conjectures than from facts. There is no doubt that the presence of closely allied representatives of our Beeches, Birches, Alders, Oaks, Limes, \&c., in the Tertiary deposits of central and southern Europe is fully proved by inflorescences and fruits as well as leaves; but how can we establish the successive changes of character in a race when we have only the inflorescence of one period, the fruit of another, and the leaf of a third? I do not find a single case in which all three have been found in more than one stage, and by far the great majority of these fossil species are established on the authority of detached leaves or fragments of leaves alone.

Now let us consider for a moment what place a leaf really holds in systematic botany. Would any experienced systematic botanist, however acute, on the sole examination of an unknown leaf, presume to determine, not only its natural order and genus, but its precise characters as an unpublished species? It is true that monographists have sometimes published new species founded on specimens without flower or fruit, which from collateral circumstances of habitat, collector's notes, general resemblance, \&c., they had good reason to believe really belonged to the genus they were occupied with; but then they had the advantage of ascertaining the general facies derived from insertion, relative position, presence or absence of stipular appendages, \&c., besides the data supplied by the branch itself. And with all these aids even the elder De Candolle, than whom no botanist was more sagacious in judging of a genus from general aspect, was proved to have been in several instances far wrong in the genus, and even order, to which he had attributed species described from leaf specimens only. Palæontologists, on the other hand, have, in the majority of these Tertiary deposits, had nothing to work upon but detached leaves or fragments of leaves, exhibiting only outward form, venation, and, to a certain degree, epidermal structure, all of which characters may be referred to that class which Professor Flower, in his introductory lecture at the Royal College of Surgeons in February last, has so aptly designated as adaptive, in contradistinction to essential and fundamental characters. They may, when taken in conjunction with relative individual abundance, assist in forming a general idea of the aspect of vegetation, and thus give some clue to certain physical conditions of the country; but they alone can afford no indication of genetic affinity, or consequently of origin or successive geographical distribution.

Lesquereux, in speaking of Cretaceous "species, or rather forms of leaves," observes in a note to his paper on Fossil Plants from Nebraska (Silliman's fournal, vol. xivi. July I868, p. I03), that "it is well understood that when the word specics is used in an examination of fossil plants, it is not taken in its precise sense, for indeed no species can be established from leaves or mere fragments of leaves. But as palæontologists have to recognise these forms described and figured, to compare them and use them for references, it is necessary to affix to them specific names, and therefore to consider them as species." But the investigators of the Tertiary floras of Central and Southern Europe have acquired the habit, not only of neglecting this distinction, and naming and treating these forms of leaves as species equivalent to those established on living plants, but of founding upon them theories which must fall to the ground if such specific determination proves inaccurate. Nothing can be more satisfactory than such determinations as that of Podogonizum for instance, which Professor Heer has succeeded in proving, by numerous specimens of leaves, fruits, and even flowers, some of them still attached to the branches, which I had myself the pleasure of inspecting last summer under the friendly guidance of the dis tinguished Professor himself. This genus of Cresalpineæ, from its evident affinity with Peltogyne, Tamarindus and others now scattered over the warmer regions of America and Africa, and more sparingly in Asia, tells a tale of much significance as to the physico-geographical relations of the Swiss Tertiary vegetation, confirmed as it is by some other equally, or almost equally, convincing examples. But the case appears to me to be far different from the theory so vividly expounded by Professor. Unger in $\mathrm{r} 86 \mathrm{I}$ in his Address entitled "Neu Holland in Europa ;" this generally admitted theory seems to me to be established on some such reasoning as this:- There are in the Tertiary deposits in Europe, and especially in the earlier ones, a number of leaves that look like those of Proteacere; Proteacer are a distinguishing feature in Australian vegetation ; ergo, European vegetation had in those times much of an Australian type derived from a direct land communication with that distant region.

This conviction that Proteacee, belonging to Australian genera, were numerous in Europe in Eocene times, is indeed regarded by palæontologists as one of the best proved of their facts. They enumerate nearly 1oo Tertiary species, and most of them with such absolute confidence that it would seem the height of presumption for so inexperienced a palæontologist as myself to express any doubt on the subject. And yet, although the remains of the Tertiary vegetation are far too scanty to assert that Proteacer did not form part of it, I have no hesitation in stating that I do not believe that a single specimen has been found that a modern systematic botanist would admit to be Proteaceous, unless it had been received from a country where Proteacex were otherwise known to exist. And, on other grounds, I should be most unwilling to believe that any of the great Australian branches of the order ever reached Europe. As this is a statement requiring much more than mere assertion on my part, I shall beg to enter into some detail, commencing with a short summary of my grounds of disbelief in European Tertiary Proteacez, and then examining into the supposed evidences of their existence.

The analysis and detailed descriptions I have had to make 
within the last few months of between five and six hundred Proteacer, and consequent investigation of their affinities and distribution have shown that the order as a whole is one of the most distinct and most clearly defined amongst Phanerogams. I do not know of a single plant intermediate in structure between that and the nearest allied orders, which I cannot say of any other of the large orders I have worked upon, There is, moreover, especially amongst the Nucamentaceæ, a remarkable definiteness in the majority of genera without intermediate species, whilst the whole order exhibits the greatest uniformity in some of its most essential characters, derived from the arrangement of the floral organs and the structure of the ovary and embryo, accompanied by a truly Protean foliage. All this points, in my mind, to unity of origin, very great antiquity, and long isolation in early times. And the species themselves appear to be for the most part constitutionally endowed with what I designated in my last year's address as individual durability rather than with rapidity of propagation. The order may be divided into about five principal groups, more or less definite in character, but very different in geographical distribution. First, the Nucamentacer (from which I would exclude Andripelatum and Guevina), which we may suppose to be the most ancient, and perhaps the only one in existence where Proteacee inhabited some land in direct communication, either simultaneously or consecutively, with extratropical Africa and Australia; for it is the only group now represented in the former. It is pre-eminently endowed with the characteristic definiteness and durability of the order. It is very natural as a whole; it has about 250 species in eleven distinct African genera, and nearly 200 species in twelve equally clistinct Australian genera, no single genus common to the two countries, and the species mostly abundant in individuals in very restricted localities. In both countries it is chiefly confined to the south. Africa sends only one or two species northward, as far as Abyssinia. The Australian portion has extended to New Zealancl, where it has left a single species, now quite differentiated from the Australian ones; very few species (not half-a. dozen) have reached tropical Australia ; and, if ever it extended farther, no representatives have yet been discovered in America, Asia, or even in New Caledonia. The four remaining groups, constituting the Folliculares, must have all been formed since the isolation from Africa. I. Banksiex, two genera, with above roo species, have the type of distribution of the Australian Nucamentaceæ, chiefly southern, local, and abundant in individuals, with three or four species penetrating into the tropics, but none beyond Australia 2. Grevilleex, in which the genera are somewhat less definite and the distribution more extended, have above 300 species in about eight genera, of which the greater portion are still southern and local; but yet a considerable number are tropical, and a few extend to New Caledonia, although none beyond that. 3. Embothrier, with about twenty-five species in half a dozen genera, form part of that sonthern, chiefly mountain, flora which extends from Tasmania and Victoria to New Zealand, Antarctic and Chilian America, a flora which comprises many species which we might imagine to have spread from the northern hemisphere down the Andes to Antarctic America, and thence to New Zealand and Australia, whilst others may have extended in a contrary direction; and amongst these we may conjecturally include the Embothriex, which in America are not found farther north than Chile; whilst in Austra!ia, although chiefly from the southern and eastern mountains, two or three species are northern, and one or two more are found in New Caledonia, but none in the Indian Archipelago, nor in Continental Asia. 4. We have lastly the tropical form of Proteacer, the Helicier, which are but a slight modification in two different directions (modifications either of the flower or of the fruit) of the Grevillea type, probably of a comparatively recent date; and although now widely spread over South America and Asia, have, nevertheless, left representatives in the original Grevillea regions of Australia. There are nearly 100 species in about eight genera, almost all tropical or subtropical; three small genera are exclusively Australian ; Helicia itself is Asiatic, chiefly from the Archipelago, extending, in four species, to tropical Australia ; in one or two species to New Caledonia; in two or three northward to the mountains of Bengal and Sikkim; and in one species even to Japan. Two American genera, with about forty species, are represented in New Caledonia by one genuine species of each, and one of an allied genus or section; and in tropical Australia by one species showing still the Australian connection; and two small genera are, as far as hitherto known, exclusively American; and may have been there diffe- rentiated. No Heliciex, nor indeed, as already observed, any Folliculares, have hitherto been discovered in Africa. If, therefore, Proteacere have really ever extended to Europe, it would naturally be in this Helicioid group that we should seek for them. As far, however, as I can learn, among the supposed century of European Proteacere, there is only one which palreontologists refer to it, the Helicia sotzkiana of Ettingshausen, founded on a single leaf, which Ettingshausen himself admits to bear much resemblance to the leaves of about twenty genera in thirteen different families; and, upon much consideration, he thinks it rather more like a Holicia than anything else, and therefore definitively names it as such, a decision in which it is difficult to concur.

In answer to the above negative considerations, which, after all, lead to presumption only, we are told that we have positive evidence of the existence of Proteacer in the Miocene, and still more in the Eocene formations of Europe, in leaves, fruits, and seeds. As none of these have been found attached to the branches nor even in sufficiently abundant proximity to be matched with anything like certainty, we must take the three separately. First, as to seeds, those referred by palreontologists to Proteacee are winged and samaroid, some of them probably real seeds, shaped, without doubt, like those of some Hakece and Embothria, but quite as much like those of several Coniferæ, or of certain genera of Meliaceæ, Sapindaceæ, and various other Dicotyledonous orders, there being no evidence of internal structure, conformation of the embryo, \&c., by which alone these several samaroid seeds can be distinguished. Moreover, those figured by Ettingshausen in his paper entitled "Die Proteacex der Vorwelt" (Proc. Imp. Acad. Sc. Vienna, vii. 7II, t. xxxi. f. II, $12,1_{4}, 15$, and $\left.\delta\right)$, have a venation of the wing very different from that of any Proteacer I have seen, and much more like that of a real samara of an ash. Next, as to fruits, the hard follicles or nuts of Proteaceæ are as remarkable for their durability as the capsules of so many Australian Myrtacere; and we should be led to expect that, where Proteaceous remains are abundant, they should include a fair proportion of fruits, as is the case with the Conifers, Leguminosa, \&c., which have been undoubtedly identified. These supposed Proteaceous fruits in the Tertiary deposits are, however, exceedingly rare. The only ones I have seen figured are: (I) a supposed Embothrium fruit figured by Heer in his Tertiary Flora of Switzerland (t. xcyii. f. 3o), an outline impression, with a deficiency in the upper portion, and without indication of internal structure; if this deficiency were filled up, and the seeds inserted, as in the imaginary restoration, f. 3I (for which I see no warrant, and in which the seeds are in the wrong position), it would be something like, but to my eyes not much like, the follicle of an Embothrium, and quite as much like what Ettingshausen figures (t. xxxi. f. 5) as the veinless leaf of a Lambertia ; and (2) the supposed Persoonice and Centarthenes drupes figured by Ettingshausen ( $t_{0_{i}} \mathrm{xxx}$.) The former, in the absence of all indication of structure, are quite as good, if not better, representations of young fruits of Ilex, Myoporum, and many others, as of Persoonia; and where, in figures $c$ and $d$ of the same plate, recent (unripe) Persoonia fruits are inserted, for comparison, with the fossil figures $\beta, \gamma$, and $\delta$, it appears to me that in the latter the long point is the pedicel, and the short point the style, whilst in the former, on the contrary, the short point is the pedicel, and the long one the style. To suppose that fig. 5 of the same plant represents the fruit of a Cenarricnes, which, as far as known, has always an obliquely globular drupe, requires indeed a great strain upon the imagination. I can find no other fossil Proteaceous fruit figured or described.

Lastly, with regard to leaves, necessarily the mainstay of palæontologists, I must admit that there is a certain general facies in the foliage of this order that enables us in most, but not in all cases, to refer to it with tolerable accuracy leafy specimens known to have come from a Proteaceous country, even without flowers or fruit; but as to detached leaves, I do not know of a single one which, in outline or venation, is exclusively characteristic of the order, or of any one of its genera. If we know the genus and section of a specimen, we may determine its species by the venation; and we may sometimes fairly guess at its genus if we know it to be Proteaceous; but that is all. Outline is remarkably variable in many species of Crevillea and others, and venation is not always constant even on the same individual. But then we are told, with the greatest confidence, that the structure of the stomata in these fossil leaves, as revealed by the microscope, proves them beyond all doubt to be Proteaceous. In reply to that, I can only refer to the highest authority on these 
curious organs, Hugo Mohl, who, in a very careful and elaborate memoir specially devoted to the somata of Proteacex, has the following passage ("Vermischte Schriften," p. 248):- "Striking as is the above-described structure of the stomata in Proteacex, we should, nevertheless, not be justified in regarding this as a peculiarity of this family; for all the variations which we meet with in the structure of the stomata in Proteaceæ are also to be found in plants belonging to widely distant orders."

From the above considerations, I cannot resist the opinion that all presumptive evidence is against European Proteacex, and that all direct evidence adduced in their favour has broken down upon cross-examination. And however much these Eocene leaves may assume a general character, which may be more frequent in Australia (in Proteaceæ and other orders) than elsewhere, all that this would prove would be, not any genetic affinity with Australian races, but some similarity of causes producing similarity of adaptive characters.

Another series of conclusions drawn by palæontologists from their recent discoveries, which appears to me to have been carried too far, relates to the region where a given species originated. The theory that every race (whether species or group of species derived from a single one) originated in a single individual, and consequently in one spot, from which it has gradually spread, is a necessary consequence of the adoption of Darwinian views; and when Mr. R. Brown ("On the Geographical Distribution of Conifers," Trans. Bot. Soc. Edin. x. p. 195) sneers at my having qualified it as a perfect delusion, he must have totally misunderstood, or rather misread, the passage he refers to in my last year's address. The expression is there specially applied to the idea of general centres ot creation, whence the whole flora of a region has gradually spread, in contradistinction to the presumed origin of individual races in a single spot, which is there as distinctly admitted. The determination of where that spot is for any individual race is a far more complicated question than either geographical botanists or palrentologists seem to suppose. "Every vegetable species," as well observed by Prof. Heer, "has its separate history," and requires a very careful comparison of all the conclusions deducible as well from present distribution as from ancient remains. The very important fact that Taxodium distichum, Sequoice, Magnolia, Salisburia, \&c., existed in Spitzberg in Miocene times, so satisfactorily proved by Heer, shows that the vegetation of that country then comprised species and genera now characteristic of North America; but it appears to me that the only conclusion to be drawn (independently of climate and geology) is, that the area of these species and genera had extended continuously from the one country to the other, either at some one time or during successive periods. The proposition that "Spitsberg appears to have been the focus of distribution of Taxodium distichum," because an accidental preservation of its remains shows that it existed there in the Lower Miocene period, would require at least to be in some measure confirmed by a knowledge of the flora of the same and preceding periods over the remainder of its present area, the greater part of which flora is however totally annihilated and for ever concealed from us. The fact that Pinus abies existed in Spitsberg in Miocene times, and that no trace of it has been found in the abundant Tertiary remains of Central Europe, is very instructive. It might show that that tree was of more recent introduction into the latter than the former country; but it cannot prove that it was not still earlier in some other region, whence it may have spread successively into both territories, still less that its course of dissemination was directly from Spitsberg over Northern and Central Europe. Moreover, the determination of Finus abies is not so convincing as that of the Taxodium, resting as it does, if I correctly understand Prof. Heer's expression, on detached seeds and leaves, with a few scales of one cone, and may require further confirmation.

In the above observations it is very far from my wish to detract from the great value of Professor Heer's researches. Interested as I have been in the investigation of the history of races of plants, I have deeply felt my general ignorance of palæontology, and consequent want of means of checking any conclusions I may have drawn from present vegetation by any knowledge of that which preceded it, and the impossibility at my time of life of entering into any detailed course of study of fossils. Like many other recent botanists, I am obliged to avail myself of the general results of the labours of palæontologists, and if I have here ventured on a few criticisms, it is only as a justification of the hope that they may in some measure distinguish proved facts from vague guesses, in order that we may know how far reliance is to be placed on their conclusions.

Spontaneous generation, or Heterogeny, is a question which continues to excite much interest. It has been the subject of detailed memoirs, of violent controversies, and of popular arlicles in this country, and still more on the Continent ; but the solution of the problems still involved in doubt does not seem to me to have much advanced since I alluded to the opposing theories of Pasteur and Pouchet in my Address of 1863 . The present state of the case appears to me to be this : in the higher orders of animals every individual is known to proceed from a similar parent after sexual pairing; in most plants, and some of the lower animals, besides the result of that sexual pairing which they all are endowed with, reproduction from the parent may take place by the separation of buds, by division, or sometimes by parthenogenesis ; in some of the lower Cryptogams, the first stage in which the new beings are separated from the parent is that of spores termed agamic, from the belief that they never require previous sexual pairing, although the range of these agamic races is being gradually restricted, a remarkable advance having been recently made in this direction by Pringsheim in his paper on the pairing of the Zoospores in Pandorina and Eudorina. In all the above cases, in all organised beings which in their earlier stages are appreciable through our instruments, every individual has been proved to have proceeded in some stage or another from a similarly organised parent. But there are cases where living beings, Vibrios, Bacteria, \&c., first appear under the microscope in a fully formed state, in decaying organic substances in which no presence of a parent could be detected or supposed : three different theories have been put forward to account for their presence : first, that they are suddenly created out of nothing, or out of purely inorganic elements, which is perhaps the true meaning disguised under the name of spontaneous generation, a theory not susceptible of argument, and therefore rejected by most naturalists as absurd; secondly, that they are the result of the transformation of the particies of the organic substances in which they are found, without any action of parent Vibrios or Bacteria; and this appears to be what is specially termed Heterogeny; thirdly, that there existed in these organic substances germs which had proceeded from parent Vibrios and Bacterias, bit too minute for optical appreciation, and that their generation was therefore normal. The supporters of Heterogeny rely on the impossibility of accounting for the appearance of the Vibrios and Bacterias in any other manner; for they say that although you treat the medium by heat in a hermetically closed vessel in such a manner as to destroy all germs and intercept ail access, still these beings appear. This their opponents deny, if the experiments are conducted with proper care. So it was seven years ago, and so it is still, although the experiments have been frequently repeated in this country, in France, and in North America, almost always with varying results. All reasoning by analogy is still in favour of reproduction from a parent; but Heterogeny has of late acquired partisans, especially in Germany, among those who are prepared to break down the barriers which separate living beings from inorganic bodies.

Brown's celebrated theory of the Gymnospermy of Conifers and allied orders has been of late the subject of keen controversy. Objected to by Baillon, Parlatore, and others, it had been strongly supported by Caspary, Eichler, and lastly, by Hooker in his important Memoir on Welzvitschia, pubiished in our Transactions in 1863 . There the question seemed to rest till last year, when two detailed papers appeared, the one contesting, the other advocating the theory. The most elaborate is without doubt that of Gustav Sperk, in the "Memoirs of the Imperial Academy of Sciences at St. Petersburg." He gives a very fair résumé of all that had been published on the subject, and proceeds to record in detail his own observations on the structure and anatomy of the flower in a considerable number of Coniferæ, of Ephedra alata, Gnetum latifolium, and two species of Cycas, illustrated by well-executed analytical figures. He endeavours to prove, chiefly by their anatomy and development; that the coating which encloses the nucleus is carpellary, not ovular, of independent origin, always free, and often earlier developed than the nucleus-that what is wanting in gymnosperms is not the ovarium or carpellary envelope, but the ovular coating-that these plants are in fact gymnosperms in the sense of having naked nuclei and embryosacs, not naked ovules.

P. Van Tieghem, on the contrary, in the Annales des Sciences Naturelles, ser. 5, vol. x., considers the gymnospermy of the 
ovules of Conifers to be proved by the anatomical structures of the organs on which they rest. He says that, as in normal Dicotyledons, the ovules are developed from, and continuous with, the margins of carpellary leaves, but these carpellary leaves are open, variously or imperfectly developed, and constitute solitary leaves on a secondary branch in the axil of the subtending bract, this secondary branch being arrested in its development, and the carpellary leaf facing the bract; the paper is illustrated by a large number of diagrams. These two Memoirs, published simultaneously at St. Petersburg and at Paris, contain of course no reference to each other. How far each author may or may not have proved his case, I cannot now take upon myself to inquire into. Neither of them appears to have had any knowledge of the views of Professor Oliver, who in his review of Hooker's Memoir on Weiwitschia (Nat. Hist. Review, 1863) suggests the analogy of the disputed organ with the axial developments known under the name of floral discs. Both writers, however, confirm the anomalous structure of the flower in this great class of plants, and the position of the plants themselves in many respects intermediate between the higher Cryptogams and Dicotyledons, their connection with the former being clearly shown by the researches of Carruthers and other palæontologists, and with Dicotyledons through Welwitschia by Hooker in his above-mentioned Memoir.

Teratology is a subject which has again risen into importance, as aiding in the history of the variations worked upon by natural selection in the formation of species. There had always been a tendency to attribute monsters and prodigies, whether in the organic or the inorganic world, to an infraction of the laws by which natural phenomena are regulated, by the intermediate interposition ad hoc of a supreme will for temporary motives inscrutable to man, in which all that the man of science was called upon to do was to establish their authenticity, and detail their abnormities. This, however, was considered by D'Alembert as sufficient to constitute Teratology as one of the great branches of Natural History taken in its most extended sense; for in his once celebrated "Système Figuré des Connaissance Humaines," Histoire Naturelle has three great branchesUnifornite de la Nature, or the study of the laws which govern the organic or inorganic world, terrestrial and celestial ; Ecarts de la Nature, the science of prodigies and monsters; and Usages de la Nature, or arts and manufactures. Jeremy Bentham, in his "Essay on Nomenclature and Classification," of which I published a French edition now nearly half a century since, strongly criticised such a classification, "by which a middle-sized man is placed in one niche, a tall man and a short man together in another." * Mr. Galton however, in his recently published interesting researches on Hereditary Genius, shows us, after Quetelet, that even in this respect the laws which govern the deviations from the average height of man, both above and below that average, are uniform under similar conditions, and may well be studied together.

We may not, indeed, with $D^{\prime}$ Alembert, combine the history of animal and vegetable monstrosities with that of mineral monsters and celestial prodigies (whatever these may be); but the course which Biology has taken in the last few years has shown the necessity of accurately investigating in each branch all observed departures from what appears to be the ordinary course, before the real laws of that ordinary course can be ascertained. A work, therefore, in which these observed aberrations are carefully collected, tested, and methodised, cannot fail to be of great use to the physiologist, and such a work with regard to plants, the want of which, brought down to the present state of the science, I alluded to in my Address of 1864 , has now been provided for us by Dr. Masters, in his "Vegetable Teratology," - a work which we should especially like to see deposited in local libraries at home and abroad, to which observers resident in the country could have ready access. Monstrosities or deviations from the ordinary forms in plants are comparatively rare and evanescent; they can be best observed in their fresh state, and often require watching in the course of their development. Country resi-dents have the best means of doing so, and to them it is very important to have a systematic work at hand by which they can ascertain whether the aberration they have met with is one well known or of frequent occurrence, or whether it presents any new feature, adding another item to our store of data, and therefore requiring closer observation and accurate record.

* Fissay on Nomenrlature and Classification, or Chresstomathia, part ii. 1817 , p. 157, French Edition, 182,3 , p. 48 .
In making use, however, of Teratology in explanation of structure and affinities, great care is required. It is not every one who can handle these phenomena with the tact of a Darwin. In the course of my systematic labours I have met with several instances where teratologists have been led into conclusions which have proved to be far wide of the truth, owing to their having confined themselves to teratology to the neglect of homology and organogeny. This importance of teratological facts to the physiologist who is able duly to appreciate their bearing, and the discredit cast on their study owing to their misuse in hasty and incautious speculations, are alluded to in Dr. Masters's Introduction. But beyond some explanations of causes suggested by the bringing together a series of facts showing a physiological connection with each other, and with more normal formations, he enters little into the various questions the solution of which has been more or less attempted by the aid of teratology. These questions, indeed, could not have been discussed without fully working out on each occasion normal organogeny, development, and homology, and thus leading him far beyond the object of the present work, which was to present to the future physiologist such a digested record of facts as should best show their relative bearing to each other, to normal conditions, and to any observed causes of disturbance. This object appears to have been well fulfilled, and the method adopted by the author probably the best suited to the purpose. A classification, founded upon the nature of the causes inducing the several changes, might, indeed, as he observes, have been theoretically the best, but is wholly impracticable until these causes shall have been satisfactorily ascertained. For the inquiry into these causes this teratological digest supplies a record of one class of facts, a necessary one, but only one of many classes on which it must be founded.

\section{G. BENTHAM}

\section{SCIENTIFIC SERIALS}

Fournal of the Chemical Society, April r870. This number contains a "Note on some Reactions of Alcohols," by Mr. E. T. Chapman. The author finds that on distilling with caustic soda a mixture of the rotating and non-rotating amylic alcohols to dryness, the distillate contains a larger proportion of the rotating alcohol than the original liquid; and, on adding water to the residue of sodic amylate and distilling the alcohol which passes over with the water is almost free from the rotating variety. A repetition of the process renders it quite pure. He also finds that repeated treatment of the rotating alcohol by caustic soda converts it into the non-rotating. On treating amylic alcohol to which about $2 \frac{1}{4}$ per cent. of water was added with a quantity of sodium just sufficient to decompose the water, and distilling, water first passed over, followed by amylic alcohol; sodic amylate almost free from caustic soda remaining in the retort; showing that the sodium replaces the hydrogen of the alcohol in preference to that of the water. Again, on distilling a solution of caustic soda in amylic alcohol, water passed over with the alcohol, the residue being sodic amylate.- "Note on the Organic Matter contained in Air," by Mr. E. T. Chapman. Several metbods were tried for collecting the organic matter from the air before estimating its quantity. Passing the air through water in a Liebig's potash apparatus, ur even in a tube with twenty-five bulbs, did not fix the whole of the organic matters. Cotton wool and gun-cotton failed on account of their invariably containing nitrogenous bodies, which vitiated the results; the condensation of steam in the air and washing with fine spray were better, but not satisfactory. Filtering the air through asbestos paper succeeded very well, but the asbestos was difficult to manage. The process finally adopted was to pass too litres of air through a quantity of finely powdered and moistened pumice stone, placed on a piece of wire gauze, fixed on the wide end of a funnel; distilling the pumice with dilute potassic hydrate and potassic permanganate, and determining the quantity of ammonia in the distillate by Nessler's test. In crowded rooms and near an untrapped sink, the air was found to contain organic bases as well as ammonia. IOO litres of air from crowded rooms contained quantities of nitrogenous substances, producing from 0.02 to 0.35 milligrammes of ammonia. - Then follows a lecture by Dr. Gladstone on "Refraction equivalents," which has already been noticed in these columns. The number concludes with a long paper by Dr. Thudichum on "Kryptophanic acid, the normal free acid of Human Urine." From the analysis of the salts it appears to be a dibasic acid of the formula $\mathrm{C}_{5} \mathrm{H}_{9} \quad \mathrm{~N} \mathrm{O}_{5}$ or a tetrabasic acid containing $\mathrm{C}_{10} \mathrm{H}_{18} \mathrm{~N}_{2} \mathrm{O}_{20}$. 